\title{
Liofilização de Fermento Natural Utilizando Agente Crioprotetor
}

\author{
Raquel Facco Stefanello (I), Leadir Lucy Martins Fries (I), Amanda \\ Aimée Rosito Machado (I) \\ (I) UFSM - UNIVERSIDADE FEDERAL DE SANTA MARIA (Av. Roraima o 1000.Bairro \\ Camobi.Santa Maria - RS )
}

\section{Resumo}

A fermentação natural é uma técnica muito antiga e ainda hoje é utilizada para a obtenção de produtos fermentados saborosos e com aspectos de qualidade e sensoriais bem satisfatórios. O fermento natural é usado, por exemplo, na fermentação de pães artesanais e outros produtos culinários. Ele pode ser produzido de várias maneiras e com uma variedade de matérias primas. A manutenção de um fermento natural necessita de cuidados especiais e a sua utilização, na forma de um fermento natural fresco não confere uma padronização nos produtos fabricados em função das transformações durante o processo. A liofilização já vem sendo usada para a conservação de fermento biológico comercial, no entanto essa tecnologia não é muito difundida para o fermento natural em vista de ser um processo muito difícil de controlar. O objetivo desse trabalho foi produzir um fermento natural a partir de farinha de trigo branca e farinha de trigo integral e avaliar a viabilidade celular após a liofilização com diferentes concentrações de trealose $(0,10$ e $15 \%)$. A trealose é um açúcar que auxilia no processo de congelamento de amostras. Após 14 dias de fabricação do fermento natural, o mesmo foi congelado e liofilizado. Após a liofilização o pó resultante foi armazenado em embalagens metálicas, a temperatura ambiente, por 45 dias. Foram realizadas contagens microbiológicas nas amostras de fermento natural antes e após o processo de liofilização para avaliar o efeito da trealose sobre as células dos microrganismos. Essas análises foram efetuadas de 15 em 15 dias após o

\footnotetext{
Referência:

Raquel Facco Stefanello, Leadir Lucy Martins Fries, Amanda Aimée Rosito Machado.Liofilização de Fermento Natural Utilizando Agente Crioprotetor. In: Anais do 12 Congresso Latinoamericano de Microbiologia e Higiene de Alimentos - MICROAL 2014 [= Blucher Food Science Proceedings, num.1, vol.1]. São Paulo: Editora Blucher, 2014.

DOI 10.5151/foodsci-microal-132
} 
processo de liofilização. Com este trabalho, observou-se um efeito crioprotetor nas amostras de fermento natural liofilizado contendo 10 (FNL 10) e $15 \%$ (FNL 15) de trealose pelas contagens microbiológicas de bactérias ácido láticas (BAL) e de bolores e leveduras (LEV) durante os 45 dias de armazenamento das amostras após o processo de liofilização. A partir desses dados, foi possível concluir que a liofilização de fermento natural é viável durante o tempo estudado e que essa tecnologia pode ser útil para a preservação das características de um fermento natural otimizando um processo rústico e artesanal para um processo mais avançado e com possibilidade de uso industrial.

Palavras-Chave: Fermento natural, Trealose, Liofilização, Viabilidade celular Agência de Fomento: 